\title{
IODONIUM POLYIODIDE CRYSTALS IN THE FRAMEWORK OF PERIODIC CALCULATIONS WITH LOCALIZED ATOMIC BASIS SETS
}

\author{
I.D. Yushina, iushinaid@susu.ru \\ E.V. Bartashevich, bartashevichev@susu.ru \\ South Ural State University, Chelyabinsk, Russian Federation
}

\begin{abstract}
Methodological features of the crystal structure modeling for compounds with three-center halogen bond formed by two electron donors $\mathrm{S}-\mathrm{I}^{+}-\mathrm{S}$ in polyiodide crystals were considered within the framework of periodic calculations based on localized atomic orbitals. The analysis of applying the different basis sets, effective core potentials, density functional theory functionals, and Grimme dispersion corrections revealed their effect on the geometric, electronic and vibrational properties obtained in calculations. Distribution of S-I bond lengths in $\mathrm{S}-\mathrm{I}^{+}-\mathrm{S}$ fragment was analyzed. The effect of hybrid functional was demonstrated in the significant elongation of S-I distance. The treatment of dispersion interactions via Grimme approach did not significantly influence obtained results. The calculated vibration modes in medium wavenumber region of characteristic cationic stretching vibrations were validated according to experimental Raman spectra and were found to be in good agreement for $\mathrm{C}-\mathrm{N}, \mathrm{C}-\mathrm{C}$ and $\mathrm{C}=\mathrm{S}$ stretching vibrations. Small-core effective potential was shown to be effective for representation of bond lengths in $\mathrm{S}-\mathrm{I}^{+}-\mathrm{S}$ fragment and gave reasonable results for vibrational data for cationic stretching vibrations. Taking into account relativistic effect on the level of basis set led to fine reproducibility of S-I bond lengths although in polyiodides of complex structure it should be treated with caution due to possible incorrect representation of interanionic distances.
\end{abstract}

Keywords: iodonium salt, three-center halogen bond, periodic DFT calculations, localized atomic basis set, polyiodide, Raman spectroscopy.

\section{Introduction}

Iodonium salts are a part of important group of iodine-hypervalent compounds [1] designed mainly for the purposes of organic synthesis in tasks of performing arylation reactions [2]. As an alternative to the classical halogen bond, a positively charged iodine atom can be involved in three-center halogen bond with two electron donors named as a four- electron halogen bond [3]. Due to the large electron delocalization, the structural fragments with three-center halogen bond are stable. These interactions have the covalent and electrostatic character simultaneously, nevertheless, for iodonium complexes dominates the properties of a halogen bond [4]. Depending on heteroatom binding to iodine atom one can obtain $\mathrm{C}-\mathrm{I}^{+}-\mathrm{C}[5], \mathrm{N}-\mathrm{I}^{+}-\mathrm{N}$ [6], $\mathrm{S}-\mathrm{I}^{+}-\mathrm{S}$ [7] symmetric and asymmetric derivatives. Beyond practical preparative aspects the questions of bonding inside such fragments has been considered in the series of works from different points of view: orbital approach, theoretic electron density descriptors and some others. Nevertheless this topic is still open for discussions.

Among counter anions forming iodonium salts halide anions play a main role. Iodide derivatives especially polyiodide ones have been recently obtained and studied not only in the direction of synthetic applications but for antithyroid drugs based on known affinity of iodine derivatives to the thyroid issues [8]. The novel crystalline polyiodides on the stage of their structural characterization are often studied with Raman spectroscopy, as it is a very sensitive instrument to the features of bonding within and between polyiodide units [9-12]. Thus, the task of assignment experimental Raman data is of high practical importance. Sometimes it is hardly possible due to multiple vibration bands in low wavenumber region and lack of reliable literature data about characteristic ranges of target bands. Thus, a combination of theoretic and experimental Raman spectra can give a clue to the correct solution in such particular complicated cases. From this point of view, the problem of obtaining Raman data from periodic $a b$ initio calculation is highly relevant although sometimes not so simple due to the necessity of timeconsuming calculation possible only on the facilities of supercomputer centers. 


\section{Физическая химия}

Versatile studies of electronic characteristic on the basis of periodic ab initio calculations have been performed recently for the row of organic polyiodides with N-, S-containing heterocycles $[13,14]$. Gasphase calculations which are the most widely used for structural characterization of polyiodide and iodonium salts $[15,16]$ are not the best choice as ignoring of the effect of crystal surrounding and underestimation of dispersion interactions lead to significant elongation of bond lengths as well as in the worst case total impossibility to reproduce structural features of polyiodide anion when it is composed of different subunits located on significant distances from each other. The usage of Density Functional Theory (DFT) calculations with periodic boundary conditions directly treating the infinite translations in the crystal phase can significantly improve the quality of obtained theoretic structural data. The choice of program package for modelling arises from the features of bonding taking place in typical organic crystals. Electronic features in the iodonium salts formed by organic cation and bound halide anion are manifested in rather localized distribution of electronic cloud. This fact encloses them to typical molecular crystals much more than to metal derivatives with delocalized behavior of electrons inside crystal phase. On the modern stage the treatment of periodicity and crystal symmetry in the framework of tight binding approximation can be better realized within DFT using localized atomic basis sets as implemented in the CRYSTAL17 code. The exploitation of Kohn-Sham approach lies in the task of treating interacting electrons in the static field of atomic nuclei is simplified up to analysis of movement of independent electrons in under efficient potential, including static potential of atomic nuclei as well as partial consideration of exchange interaction and electronic correlation.

The calculations of such complicated many-electron systems is impossible without the usage of theoretic approximations mainly based on one-electron approach so that each of the electrons in many electron systems moves in the field of atomic nuclei and effective field of all other electrons. Selfconsistent field procedure is based on the iterative solvation of system of equations with initially chosen zero-approximation of functions for further formation of density matrix. The cyclic calculation proceeds until the values of one-electron $\varepsilon_{j}$ and total energies $\mathrm{E}$ of the system do not coincide within the predefined delta values obtained on the previous step. Significant differences in solid state calculations in comparison to molecular ones on this step lie in the increased and infinite value of electrons in crystal. This leads to the consideration of crystal under symmetry operators so that all equivalent points of space should be put into correspondence independently on the absence or presence of atoms in these points. Thus, summation for the formation of density matrix is taken out for each occupied energy zones and inside them for each wave vector values inside Brilloiun zone. The complexity of this procedure is due to the necessity of summation on each step of self-consistent iteration over Brilloium zone. The practical usage of this task is realized using Pack-Monkhorst scaling scheme consisting of predefined net of points so that each of three vectors in the reverse cell is divided into equivalent intervals.

Localized atomic basis sets bases on Gauss-type orbitals allow reasonable treatment of both valence and core regions [17], although overall number of shells stays small-scale. Such approach is beneficial for the calculation of vibrational characteristics, [18], especially Raman ones including the high computationally demand calculation of intensity, modelling of powder and polarized spectra, consideration of experimental conditions on the level of empirical correction to temperature and laser excitation wavelength [19].

The question of relativistic effects becomes significant for heavy elements, including halogens, such as bromine and iodine. In the present study we perform an attempt to take them into account on the level of chosen basis sets from two basic approaches: one will include Douglas-Kroll-Hess methodology [20, $21]$ and the other will de due to the usage of relativistic effective core potential (ECP). It has been shown in the work [22], that relativistic effects are mainly manifested in the behavior of valence $1 \mathrm{~s}$ and $2 \mathrm{p}$ orbitals. It has been demonstrated in the work [23] that the obtaining of high-quality results in calculated electron density with ECP is possible if we use small-core potentials. Thus, a combination of these two approaches will be tested in this work.

Practical works devoted to improve the reproducibility of experimental Raman data in the calculated spectra have been recently reported for the row of polyiodides with organic heterocyclic cations of different structure and composition [9-12]. Now these observations are scaled for the tasks of simultaneous treatment of both polyiodide anions and iodonium $\mathrm{S}-\mathrm{I}^{+}-\mathrm{S}$ fragments in the present study. Thus, a computational task of this work was to examine a combination of basis sets and DFT functionals in or- 
der to better reproduce structural, electronic and vibrational parameters of crystal structures included S$\mathrm{I}^{+}-\mathrm{S}$ fragments and polyiodide anions.

\section{Calculations}

Periodic quantum chemical calculations were performed using the CRYSTAL17 program [24] with different functionals and basis sets in order to better reproduce geometric, electronic and vibrational properties of the studied objects with $\mathrm{S}-\mathrm{I}^{+}-\mathrm{S}$ fragment in the molecular structure. Localization of the equilibrium geometry of the crystal structure was carried with fixed unit cell parameters so that the results to be closer to experimental diffraction data initially chosen as starting point. K-point sampling was done using a Monkhorst-Pack grid of $8 \times 8 \times 8$. The calculations were performed on the TORNADO LSM supercomputer of South Ural State University.

Test of functionals and basis sets included standard B3LYP and PBE0 choice as well as the upgrade due to the treatment of dispersion interactions according to the scheme suggested by Grimme [25, 26]. The test of basis set included variants of the best available basis sets for iodine atoms: fully electronic DZVP basis, DZP-DKH implementing Douglas-Kroll-Hess scheme for relativistic effect [27] and fully relativistic small-core multielectron pseudopotential ECP mdf28 combined with VDZ basis for valence electrons, designed by University of Stuttgart [28]. The basis set choice for C, H, N, S, atoms was made according to CRYSTAL17 site where the TZVP basis set designed by Peintinger [29]. Theoretic Raman active modes and their intensities have been computed in couple-perturbed Kohn-Sham approach with B3LYP/TZVP, DZVP and PBE0-D3/ECP mdf28-VDZ levels of theory in order to interpret experimental spectra and assign multiple low-wavenumber bands. Hessian matrix calculation was extremely timeconsuming due to large size of crystallographic cell consisting of 42 atoms in the symmetrically independent part of the cell. The calculation of three displacements of each atoms in three directions took approximately 20 hours on 10 nodes in parallel, so that overall calculations take more than a month for each level of theory.

\section{Results and Discussion}

Analysis of CSD ver. 2020.1 [30] in order to find structures with similar $\mathrm{S}-\mathrm{I}^{+}-\mathrm{S}$ fragment resulted in 9 examples of independent crystal structures (no disorder, only organic), the summary of their structural parameters is presented in Table 1 and Fig. 1 . S- $-{ }^{+}-\mathrm{S}$ fragment can be either noncentrosymmetric with different $\mathrm{S}-\mathrm{I}$ bond lengths depending on S-derived fragments and the crystal structure surrounding or centrosymmetric with equal S-I distances.

Structural parameters in S-I+ $\mathbf{S}$ fragment in considered crystal structures

Table 1

\begin{tabular}{|c|c|c|c|c|c|}
\hline № & Organic cation compound & $\begin{array}{l}\mathrm{S}(1)-\mathrm{I}^{+} \text {bond } \\
\text { length, } \AA\end{array}$ & $\begin{array}{l}\mathrm{I}^{+}-\mathrm{S}(2) \text { bond } \\
\text { length, } \AA\end{array}$ & Anion type & Reference \\
\hline 1 & $\begin{array}{l}\text { Benzimidazole-2-thione-di-iodine } \\
\text { bis(benzimidazole-2-thio)iodonium }\end{array}$ & $\begin{array}{l}2.597 \\
2.670\end{array}$ & 2.702 & $\mathrm{I}_{3}^{-}$ & [8] \\
\hline \multirow{2}{*}{2} & \multirow{2}{*}{$\begin{array}{l}\text { Bis(N-Methylbenzo-thiazole-2- } \\
\text { thio)iodonium }\end{array}$} & 2.601 & 2.634 & $\mathrm{I}_{5}^{-} \ldots \mathrm{I}_{2}$ & [31] \\
\hline & & 2.592 & 2.624 & $\mathrm{I}_{5}^{-} \ldots \mathrm{I}_{2}$ & [32] \\
\hline 3 & $\begin{array}{l}\text { Bis(5-trifluoromethyl-pyridinium- } \\
\text { 2-thio)iodonium triiodide }\end{array}$ & 2.597 & 2.691 & $\mathrm{I}_{3}^{-}$ & {$[33]$} \\
\hline 4 & Bis(thiourea)iodine iodide & 2.629 & 2.629 & $\mathrm{I}^{-}$ & [34] \\
\hline 5 & $\begin{array}{l}\text { Bis(1,3-Dimethyl-2-thiourea- } \\
\text { S)iodonium tri-iodide }\end{array}$ & $\begin{array}{l}2.602 \\
2.623\end{array}$ & $\begin{array}{l}2.654 \\
2.635\end{array}$ & $2 \mathrm{I}_{3}^{-}$ & {$[35]$} \\
\hline 6 & 2-Imidazolidinethione & 2.628 & 2.630 & $\mathrm{I}^{-}, \mathrm{I}_{3}^{-}$ & {$[36]$} \\
\hline \multirow{2}{*}{7} & \multirow{2}{*}{$\begin{array}{l}\text { 5-Methyl-1,3,4-thiadiazole-2 }(3 H) \text { - } \\
\text { thione iodonium pentaiodide }\end{array}$} & 2.623 & 2.638 & $\mathrm{I}_{5}^{-}$ & [7] \\
\hline & & 2.624 & 2.645 & $\mathrm{I}_{5}^{-}$ & [37] \\
\hline 8 & $\begin{array}{l}\text { Bis(thiazoline-2-thione)-iodonium } \\
\text { polyiodide }\end{array}$ & 2.654 & 2.654 & $\mathrm{I}_{3}^{-} \ldots \mathrm{I}_{2}$ & [38] \\
\hline 9 & $\begin{array}{l}\text { 4-Phenyl-5H-1,2,3-dithiazole-5- } \\
\text { thione polyiodide }\end{array}$ & 2.629 & 2.631 & $\mathrm{I}_{3}^{-} \ldots \mathrm{I}_{2}$ & [39] \\
\hline
\end{tabular}


<smiles>I[SH]=C1NC2C=CCCCC2N1</smiles>

1<smiles>CN1C(S[I+]SC2SC3CCCCC3N2C)SC2CCCCC21</smiles>

2<smiles>FC(F)(F)C1CCC(S[I-]CSC2CCC(C(F)(F)F)NN2)NC1</smiles><smiles>NNC(N)SC[Te]SC(N)N</smiles>

4<smiles>CNC(S[I+]SC(NC)N(C)NC)N(C)N</smiles>

5<smiles>C(SC1NCCS1)=[Te]SC1NCCS1</smiles>

8<smiles>C1CNC(S[Te]SC2NCCN2)N1</smiles>

6<smiles></smiles>

7<smiles></smiles>

Fig. 1. Cations formed by tree-center halogen bonds whith iodonium atom

The structure of bis(1,3-Dimethyl-2-thiourea-S)iodonium tri-iodide 5 exhibits in its composition two $\mathrm{S}-\mathrm{I}^{+}-\mathrm{S}$ fragments with different bond lengths. Crystal structure of (benzimidazole-2-thione-di-iodine) (bis(benzimidazole2-thio)iodonium) 1 represents an interesting example of simultaneous existence in one crystal structure of two limit cases of bonding: S- $\mathrm{I}^{+}-\mathrm{I}$ and $\mathrm{S}-\mathrm{I}^{+}-\mathrm{S}$. The distribution of $\mathrm{S}-\mathrm{I}$ bond lengths in the structures from Table 1 is presented in Fig. 2, where blue columns correspond to the shortest bond length, while the red ones - to the longer ones between two neighboring bonds in $\mathrm{S}-\mathrm{I}^{+}-\mathrm{S}$ fragment.

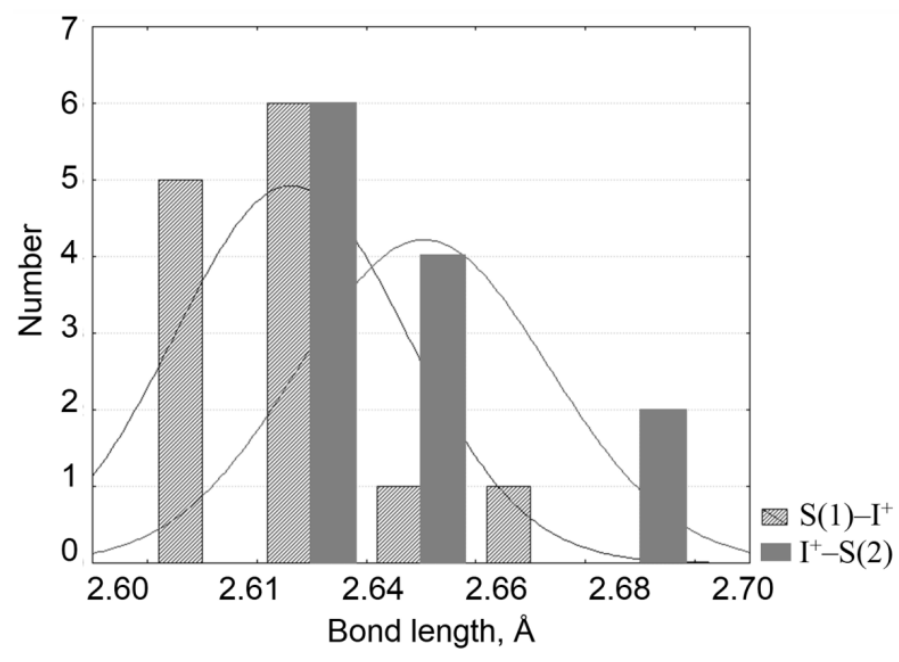

Fig. 2. Distribution of S-I bond lengths in $\mathrm{S}-\mathrm{I}^{+}-\mathrm{S}$ fragments selected for analysis

The close attention to the modelling of $\mathrm{S}-\mathrm{I}^{+}-\mathrm{S}$ fragment originates from the iodonium salt based on dithiazole derivative 9, fragment of its structure is presented in Fig. 1. The crystal struture 9 demonstrates typical values of S-I bond length in almost symmetrical S-I ${ }^{+}-\mathrm{S}$ fragment: 2.629 and $2.631 \AA$ according to Fig. 2. Multiple polyiodide subunits as well as $\mathrm{S}-\mathrm{I}^{+}-\mathrm{S}$ fragment altogether made this structure a tricky task for theoretical approach. The results of performed calculations for the structures $\mathbf{4 , 8}$ and 9 are summarized in Table 2. Note that the Table 2 illustrates the results of varying basis sets for iodine atoms and invariable TZVP basis set for the rest C, N, S, H atoms. It can be seen that B3LYP choice leads to the largest elongation of S-I bond in 9, the change to PBE0 with the same DZVP set gives more reasonable results. Although the test cases reveal good agreement with experiment $(\Delta=+0.011 \AA$ for $\mathbf{4}$ and $0.009 \AA$ for $\mathbf{8})$, still for $\mathbf{9}$ this approximation leads to increase of asymmetry between two 
$\mathrm{S}-\mathrm{I}$ bonds in $\mathrm{S}-\mathrm{I}^{+}-\mathrm{S}$ fragment (difference between two bond length is $0.028 \AA$ instead of $0.002 \AA$ in experiment) and addition of Grimme dispersion correction for better treatment of noncovalent interactions does not improve the data. The shift to DKH scheme or the usage of relativistic ECP potential both lead to significant improvement: $\Delta=0.01 \Delta$ for shorter $\mathrm{S}-\mathrm{I}$ bond and $0.012 \AA$ for longer one, the difference between them is ideally consistent with the experiment.

DFT functionals and atomic localized basis sets influence the S-I bond lengths in crystals with S-I+-S fragment

Table 2

\begin{tabular}{|c|c|c|c|c|}
\hline Object / Level of theory & \multicolumn{2}{|c|}{ S-I lengths $(\AA)$ before optimization } & \multicolumn{2}{|c|}{ S-I lengths $(\AA)$ after optimization } \\
\hline 4 / B3LYP, DZVP (I) & \multirow{5}{*}{\multicolumn{2}{|c|}{2.629}} & \multicolumn{2}{|c|}{2.678} \\
\hline 4 / PBE0, DZVP (I) & & & \multicolumn{2}{|c|}{2.639} \\
\hline 4 / PBE0-D3, DZVP (I) & & & \multicolumn{2}{|c|}{2.640} \\
\hline 4 / PBE0-D3, DZP-DKH (I) & & & \multicolumn{2}{|c|}{2.634} \\
\hline 4 / PBE0-D3, 28mdf-vdz (I) & & & \multicolumn{2}{|c|}{2.627} \\
\hline 8 / PBE0-D3, DZVP (I) & \multicolumn{2}{|c|}{2.654} & \multicolumn{2}{|c|}{2.663} \\
\hline 9 / B3LYP, DZVP (I) & \multirow{5}{*}{2.629} & \multirow{5}{*}{2.631} & 2.684 & 2.715 \\
\hline 9 / PBE0, DZVP (I) & & & 2.639 & 2.667 \\
\hline 9 / PBE0-D3, DZVP (I) & & & 2.640 & 2.667 \\
\hline 9 / PBE0-D3, DZP-DKH (I) & & & 2.639 & 2.643 \\
\hline 9 / PBE0-D3, 28mdf-vdz (I) & & & 2.640 & 2.643 \\
\hline
\end{tabular}

Another point of consideration for the choice of theoretic approximation is the reproducibility of bond length and intermolecular distances in the anionic part of the cell. As an example the structure $\mathbf{9}$ has been chosen due to the diversity of I...I and I...S noncovalent interactions in its structure. Their correct treatment in theory can be extremely essential for the obtaining of fine spectral characteristics. Thus, from the point of correct anion treatment PBE0-D3 DZVP-DKH is not the best choice. It is because of such basis set integrates both $\mathrm{I}_{3}{ }^{-}$and $\mathrm{I}_{2}$ in one discrete anion by significantly decreasing the distance between terminal atoms in triiodide anion and diiodine molecule $(-0.27 \AA)$ and increasing the length of covalent bond in another diiodine molecule $(+0.61 \AA)$ located on the other side of the triiodide anion.

Calculated vibrational properties of the studied compound 9 should be validated with respect to experiment in medium wavenumber region below $1700 \mathrm{~cm}^{-1}$ typical for the vibrations of heterocyclic dithiazolium cation (Table 3).

Table 3

Experimental bands [39] and calculated Raman active modes of 9 and their assignment, bold corresponds to the bands of high intensity

\begin{tabular}{|c|c|c|c|}
\hline \multirow[b]{2}{*}{ Experiment, $\omega_{\exp }, \mathrm{cm}^{-1}$} & \multicolumn{2}{|c|}{ Calculations, $\omega_{\text {calc }}, \mathrm{cm}^{-1}$} & \multirow[b]{2}{*}{$\begin{array}{l}\text { Assignment of experimental bands } \\
\text { and calculated modes }\end{array}$} \\
\hline & $\begin{array}{l}\text { B3LYP/TZVP, } \\
\text { DZVP }\end{array}$ & $\begin{array}{c}\text { PBE0-D3, } \\
\text { TZVP, } \\
\text { mdf } 28 v d z\end{array}$ & \\
\hline 480 & 467 & 483 & Stretching, v S-S \\
\hline 603,617 & 610 & 618 & In-plane bending of dithiazole ring \\
\hline 647 & 666 & 669 & In-plane bending of benzene ring \\
\hline 861 & 881 & 854 & Stretching, v N-S, v C-S \\
\hline 1024 & 1030 & 1026 & $\delta$ benzene ring $+\delta \mathrm{C}-\mathrm{H}$ \\
\hline 1040 & 1053 & 1036 & bending of benzene + dithiazole ring \\
\hline 1123 & 1156 & 1177 & Stretching, v $\mathrm{C}-\mathrm{C}$, v $\mathrm{C}=\mathrm{S}$ \\
\hline 1268 & 1299 & 1319 & Stretching, v $\mathrm{C}-\mathrm{C}$ \\
\hline
\end{tabular}

It is worth noting, that in consistence with geometrical characteristics presented in the table 2 and 3 the reproducibility of spectral characteristics of polyiodide anion part is better using B3LYP/DZVP, TZVP model, while the positions of bending vibrations in the region $200-1000 \mathrm{~cm}^{-1}$ is better reproduced by PBE0D3 level of theory with small-core fully relativistic ECP mdf28. The reproducibility of characteristic bands in both cases was reasonable, the calculated bands of stretching $\mathrm{C}-\mathrm{C}$ and $\mathrm{C}=\mathrm{S}$ vibrations were overestimated for average $30 \mathrm{~cm}^{-1}$ for B3LYP and $50 \mathrm{~cm}^{-1}$ for PBE-D3 mdf28vdz which is consistent with precomputed scaling factors for standard functionals: for example, the scaling factor 0.965 for the B3LYP/TZVP combination of basis set and functional. 


\section{Физическая химия}

\section{Conclusions}

In this research, we have studied the methodological questions of theoretic treatment of iodonium salts with $\mathrm{S}-\mathrm{I}^{+}-\mathrm{S}$ fragment coexisting with polyiodide anion. As a result of the study, the following generalizations can be formulated: low-wavenumber region of Raman active vibrations is better described with PBE0-D3 ECP mdf28 approximation, geometric characteristic of $\mathrm{S}^{-} \mathrm{I}^{+}-\mathrm{S}$ fragment are adequately described by PBE0-D3 with DZVP and DZP-DKH. Nevertheless, DZP-DKH basis set in combination with PBE0-D3 completely disturbs inter- and intra-anion distances in 4-Phenyl-5 H-1,2,3-dithiazole-5thione polyiodide, so it should be used with caution to model anions with complex structures consisting of several polyiodide units. Grimme dispersion D3 correction does not significantly influence on the bond lengths within $\mathrm{S}-\mathrm{I}^{+}-\mathrm{S}$ fragment although it drastically changes the lengths between triiodide and diiodine subunits. The main challenges for all tested basis sets were the lengths of bound diiodine molecule, which in all the cases were significantly elongated: $+0.034 \AA$ in the best case for mdf 28 -vdz.

\section{Acknowledgements}

This study is supported by RFBR № 20-03-00240.

\section{References}

1. Yoshimura A., Zhdankin V.V. Advances in Synthetic Applications of Hypervalent Iodine Compounds. Chem. Rev., 2016, vol. 116, no. 5, pp. 3328-3435. DOI: 10.1021/acs.chemrev.5b00547.

2. Zhdankin V.V, Stang P.J. Alkynyliodonium Salts in Organic Synthesis. Tetrahedron, 1998, vol. 54, no. 37, pp. 10927-10966. DOI: 10.1016/S0040-4020(98)00410-4.

3. Turunen L., Erdelyi M. Halogen Bonds of Halonium Ions. Chem Soc Rev., 2020, vol. 49, pp. 2688-2700. DOI: 10.1039/d0cs00034e.

4. Karim A., Reitti M., Carlsson A.-C.C., Gräfenstein J., Erdelyi M. The Nature of $[\mathrm{N}-\mathrm{Cl}-\mathrm{N}]^{+}$and $[\mathrm{N}-$ F-N]+ Halogen Bonds in Solution. Chem. Sci., 2014, vol. 5, pp. 3226-3233. DOI: 10.1039/C4SC01175A.

5. Lindstedt E., Reitti M., Olofsson B. One-Pot Synthesis of Unsymmetric Diaryliodonium Salts from Iodine and Arenes. J. Org. Chem., 2017, vol. 82, no. 22, pp. 11909-11914. DOI:10.1021/acs.joc.7b01652.

6. Carlsson A.C., Mehmeti K., Uhrbom M., Karim A., Bedin M., Puttreddy R., Kleinmaier R., Neverov A.A., Nekoueishahraki B., Gräfenstein J., Rissanen K., Erdélyi M. Substituent Effects on the [NI-N]+ Halogen Bond. J. Am. Chem. Soc., 2016, vol. 138, no. 31, pp. 9853-9863. DOI: $10.1021 /$ jacs.6b03842.

7. Tamilselvi A., Mugesh G. Interaction of Heterocyclic Thiols/thiones Eliminated from Cephalosporins with Iodine and its Biological Implications. Bioorg. Med. Chem. Lett., 2010, vol. 20, no. 12, pp. 3692-3697. DOI: 10.1016/j.bmcl.2010.04.087.

8. Corban G. J., Hadjikakou S.K., Hadjiliadis N., Kubicki M., Tiekink E.R.T., Butler I.S., Drougas E., Kosmas A.M. Synthesis, Structural Characterization and Computational Studies of Novel Diiodine Adducts with the Heterocyclic Thioamides N-methylbenzothiazole-2-thione and Benzimidazole-2thione: Implications with the Mechanism of Action of Antithyroid Drugs. Inorg. Chem., 2005, vol. 44, no. 23, pp. 8617-8627. DOI: 10.1021/ic0484396.

9. Yushina I., Tarasova N., Kim D., Sharutin V., Bartashevich E. Noncovalent Bonds, Spectral and Thermal Properties of Substituted Thiazolo[2,3-b][1,3]thiazinium Triiodides. Crystals, 2019, vol. 9, no. 10,506 . DOI: $10.3390 /$ cryst9100506.

10. Bartashevich E.V., Batalov V.I., Yushina I.D., Stash A.I., Chen Y.S. Nontypical Iodinehalogen Bonds in the Crystal Structure of (3E)-8-chloro-3-iodomethylidene-2,3-dihydro-1,4oxazino[2,3,4-ij]quinolin-4-ium Triiodide. Acta Crystallogr. Sect. C Struct. Chem., 2016, vol. 72, no. 4, pp. 341-345. DOI: 10.1107/S2053229616003934.

11. Yushina I.D., Kolesov B.A., Bartashevich E.V. Raman Spectroscopy Study of New Thia- and Oxazinoquinolinium Triodides. New J. Chem., 2015, vol. 39, no. 8, 2015, pp. 6163-6170. DOI: 10.1039/c5nj00497g.

12. Yushina I.D., Batalov V.I., Bartashevich E.V., Davydov A.O., Zelenovskiy P.S., Masunov A.E. Raman Spectroscopy and Theoretic Study of Hyperpolarizability Effect in Diiodobutenyl-bisthioquinolinium Triiodide at Low Temperature. J. Raman Spectrosc., 2017, vol. 48, no. 11, pp. 14111413. DOI: $10.1002 /$ jrs.5159. 
13. Bartashevich E., Mukhitdinova S., Yushina I., Tsirelson V. Electronic Criterion for Categorizing the Chalcogen and Halogen Bonds: Sulfur-Iodine Interactions in Crystals. Acta Crystallogr. Sect. B Struct. Sci. Cryst. Eng. Mater., 2019, vol. 75, no. 2, pp. 117-126. DOI: $10.1107 /$ S2052520618018280.

14. Bartashevich E., Yushina I., Kropotina K., Muhitdinova S., Tsirelson V. Testing the Tools for Revealing and Characterizing the Iodine-iodine Halogen Bond in Crystals. Acta Crystallogr. Sect. B Struct. Sci. Cryst. Eng. Mater., 2017, vol. 73, no. 2, pp. 217-226. DOI: 10.1107/S2052520617002931.

15. Sharp S.B, Gellene G.I. Ab Initio Calculations of the Ground Electronic States of Polyiodide Anions. J. Phys. Chem. A., 1997, vol. 101, no. 11, pp. 2192-2197. DOI: 10.1021/jp962755r.

16. Mizuno M., Tanaka J., Harada I. Electronic Spectra and Structures of Polyiodide Chain Complexes. J. Phys. Chem., 1981, vol. 85, no. 13, pp. 1789-1794. DOI: 10.1021/j150613a006.

17. Savin A. A Combined Density Functional and Configuration Interaction Method. Int. J. Quantum Chem., 1988, vol. 12, no. 19, pp. 59-69. DOI: 10.1002/qua.560340811.

18. Zicovich-Wilson C.M., Pascale F., Roetti C., Saunders V.R. The Calculation of the Vibration Frequencies of $\alpha$-quartz: the Effect of Hamiltonian and Basis Set. J. Comput. Chem., 2004, vol. 25, no. 15 , pp. $1873-1881$. DOI: $10.1002 /$ jcc. 20120 .

19. Maschio L., Kirtman B., Rerat M., Orlando R., Dovesi R. Ab Initio Analytical Raman Intensities for Periodic Systems through a Coupled Perturbed Hartree-Fock/Kohn-Sham Method in an Atomic Orbital Basis. II. Validation and Comparison with Experiments. J. Chem. Phys., 2013. vol. 139, 164102. DOI: $10.1063 / 1.4824443$.

20. Douglas M., Kroll N.M. Quantum Electrodynamical Corrections to Fine-structure of Helium. Ann. Phys., 1974, vol. 82, no. 1, pp. 89-155. DOI: 10.1016/0003-4916(74)90333-9.

21. Hess B.A. Relativistic Electronic-structure Calculations Employing a Two-component No-pair Formalism with External-field Projection Operators. Phys. Rev. A., 1986, vol. 33, pp. 3742-3748. DOI: 10.1103/PhysRevA.33.3742.

22. Pyykko P. Relativistic Effects in Structural Chemistry. Chem. Rev., 1988, vol. 88, no. 3, pp. 563-594. DOI: 10.1021/cr00085a006.

23. Neuhaus A., Veldkamp V., Frenking G. Oxo and Nitrido Complexes of Molybdenum, Tungsten, Rhenium and Osmium. A Theoretical Study. Inorg. Chem., 1994, vol. 33, no. 23, pp. 52785286. DOI: $10.1021 / \mathrm{ic} 00101 \mathrm{a} 020$.

24. Dovesi R., Saunders V.R., Roetti C., Orlando R., Zicovich-Wilson C.M., Pascale F., Civalleri B., Doll, K., Harrison N.M., Bush I.J., D’Arco P., Llunell M., Causà M., Noël Y., Maschio L., Erba A., Rerat M., Casassa S. CRYSTAL17 User's Manual (University of Torino, Torino, 2017).

25. Grimme S., Antony J., Ehrlich S., Krieg H. A Consistent and Accurate Ab Initio Parametrization of Density Functional Dispersion Correction (DFT-D) for the 94 Elements H-Pu. J. Chem. Phys., 2010, vol. 132, no. 15, p. 154104. DOI: 10.1063/1.3382344.

26. Grimme S. Semiempirical GGA-type Density Functional Constructed with a Long-range Dispersion Correction. J. Comput. Chem., 2006, vol. 27, no. 15, pp. 1787-1799. DOI: 10.1002/jcc.20495.

27. Barros C.L., de Oliveira P.J.P., Jorge F.E., Canal Neto A., Campos M. Gaussian Basis Set of Double Zeta Quality for Atoms Rb through Xe: Application in Non-relativistic and Relativistic Calculations of Atomic and Molecular Properties. Mol. Phys., 2010, vol.108, no. 15, pp. 1965-1972. DOI: 10.1080/00268976.2010.499377.

28. Peterson K.A., Shepler B.C., Figgen D., Stoll H. On the Spectroscopic and Thermochemical Properties of $\mathrm{ClO}, \mathrm{BrO}, \mathrm{IO}$, and Their Anions. J. Phys. Chem. A, 2006, vol. 110, no. 51, pp. 1387713883. DOI: $10.1021 /$ jp0658871.

29. Peintinger M.F., Oliveira D.V., Bredow T. Consistent Gaussian Basis Sets of Triple-Zeta Valence with Polarization Quality for Solid-State Calculations. J. Comput. Chem., 2012, vol. 34, no. 6, pp. 451-459. DOI: $10.1002 /$ jcc. 23153 .

30. Groom C.R., Bruno I.J., Lightfoot M.P., Ward S.C. The Cambridge Structural Database. Acta Cryst., 2016, vol. B72, pp. 171-179. DOI: 10.1107/S2052520616003954.

31. Demartin F., Deplano P., Devillanova F.A., Isaia F., Lippolis V., Verani G. Conductivity, FTRaman Spectra and X-Ray Crystal Structures of Two Novel [D2I]In ( $=3$ and $\mathrm{D}=\mathrm{N}$ methylbenzothiazole-2(3H)-selone; $\mathrm{n}=7$ and $\mathrm{D}=\mathrm{N}$-methylbenzothiazole-2(3H)-thione) Iodonium 
Salts. First example of I-.3I2 Heptaiodide. Inorg. Chem., 1993, vol. 32, no. 7, pp. 3694-3699. DOI: $10.1021 / \mathrm{ic} 00069 \mathrm{a} 025$.

32. Corban G.J., Hadjikakou S.K., Tsipis A.C., Kubicki M., Bakas T., Hadjiliadis N. Inhibition of Peroxidase-catalyzed Iodination by Thioamides: Experimental and Theoretical Study of the Antithyroid Activity of Thioamides. New J. Chem., 2011, vol. 35, no. 1, pp. 213-224. DOI: 10.1039/c0nj00626b.

33. Chernov'yants M.S., Burykin I.V., Starikova Z.A., Erofeev N.E. Synthesis, Spectroscopic and Structural Characterization of Novel Interaction Product of 5-trifluoromethyl-pyridine-2-thione with Iodine. J. Mol. Struct., 2011, vol. 1006, no. 1-3, pp. 379-382. DOI: 10.1016/j.molstruc.2011.09.035.

34. Lin G.H.-Y., Hope H. The Crystal Structure of bis(thiourea)iodine(I) Iodide. Acta Crystallographica, Section B: Struct. Crystallogr. Cryst. Chem., 1972, vol. 28, pp. 643-646. DOI: 10.1107/S0567740872002900.

35. Boyle P.D., Christie J., Dyer T., Godfrey S.M., Howson I.R., McArthur C., Omar B., Pritchard R.G., Williams G.Rh. Further Structural Motifs from the Reactions of Thioamides with Diiodine and the Interhalogens Iodine Monobromide and Iodine Monochloride: an FT-Raman and Crystallographic Study. J. Chem. Society, Dalton Transactions, 2000, pp. 3106-3112. DOI: 10.1039/b004182n.

36. Koskinen L., Hirva P., Kalenius E., Jääskeläinen S., Rissanen K., Haukka M. Halogen Bonds with Coordinative Nature: Halogen Bonding in a S-I+-S Iodonium Complex. CrystEngComm, 2015, vol. 17, 1231-1236. DOI: 10.1039/C4CE01735H.

37. Chernov'yants M.C., Aleshina N.V., Starikova Z.A., Sul'zhenko E.N. The Study of Interaction of 5-methyl-1,3,4-thiadiazoline-2-thione with Diiodine. Izvestiya Akademii Nauk, Seriya Khimicheskaya, 2010, pp. 1750.

38. Daga V., Hadjikakou S.K., Hadjiliadis N., Kubicki M., dos Santos J.H.Z., Butler I.S. Synthesis, Spectroscopic and Structural Characterization of Novel Diiodine Adducts with the Heterocyclic Thioamides, Thiazolidine-2-thione (tzdtH), Benzothiazole-2-thione (bztzdtH) and Benzimidazole-2-thione (bzimtH). Eur. J. Inorg. Chem., 2002, pp. 1718-1728. DOI: 10.1002/10990682(200207)2002:7<1718::AID-EJIC1718>3.0.CO;2-S.

39. Bol'shakov O.I., Yushina I.D., Bartashevich E.V., Stash A.I., Aysin R.R., Rakitin O.A. Structure and Properties of 4-Phenyl-5H-1,2,3-Dithiazole-5-Thione Polyiodide with $\mathrm{S}-\mathrm{I}^{+}-\mathrm{S}$ Bridged Complex. Structural chemistry, 2020, DOI: 10.1007/s11224-020-01584-y, in press.

Received 30 June 2020

Удк 544.144.22+ 544.147.4+ 544.182.4+ 544.182.7

DOI: $10.14529 /$ chem200407

\title{
КРИСТАЛЛЫ ИОДОНИЕВЫХ ПОЛИИОДИДОВ В РАМКАХ ПЕРИОДИЧЕСКИХ РАСЧЁТОВ С ЛОКАЛИЗОВАННЫМИ АТОМНЫМИ БАЗИСНЫМИ НАБОРАМИ
}

\author{
И.Д. Юшина, Е.В. Барташевич \\ Южно-Уральский государственный университет, г. Челябинск, Россия
}

\begin{abstract}
Методологические особенности моделирования кристаллической структуры соединений с трехцентровой галогенной связью $\mathrm{S}-\mathrm{I}^{+}-\mathrm{S}$, образованной двумя донорами электронов в кристаллах полииодидов рассматривались в рамках периодических квантовомеханических расчетов на основе локализованных атомных орбиталей. Анализ применения различных базисных наборов, эффективных остовных потенциалов, функционалов в теории функционала плотности и дисперсионных поправок по Гримме выявил особенности влияния выбора метода на геометрические, электронные и колебательные свойства, полученные в расчетах. Эффект влияния гибридного функционала проявлялся в значительном удлинении связи S-I. Учет дисперсионных взаимодействий на уровне эмпирической поправки Гримме существенно не влиял на качество получаемых данных. Рассчитанные моды колебаний в области средних волновых чисел характерных катионных валентных колебаний проверены на соответствие с экспериментальными спектрами комбинаци-
\end{abstract}


онного рассеяния, показано хорошее соответствие, в том числе для валентных колебаний $\mathrm{C}-\mathrm{N}, \mathrm{C}-\mathrm{C}$ и $\mathrm{C}=\mathrm{S}$. Малоостовный потенциал продемонстрировал хорошие результаты в воспроизведении длин связей в $\mathrm{S}-\mathrm{I}^{+}-\mathrm{S}$ фрагменте и колебательных характеристик в области валентных колебаний в катионе. Учет релятивистских эффектов на уровне базисного набора позволил воспроизвести длины S-I связей в кристалле, однако применение этого расчетного приближения для полииодидов сложного строения должно производиться с осторожностью из-за возможного искажения расстояний между полииодидными субъединицами.

Ключевые слова: йодониевые соли, трехцентровая галогеновая связь, периодические DFT-расчеты, локализованный атомный базисный набор, полииодид, спектроскопия комбинационного рассеяния.

Юшина Ирина Дмитриевна - кандидат химических наук, научный сотрудник, НИЛ многомасштабного моделирования многокомпонентных функциональных материалов НОЦ «Нанотехнологии», Южно-Уральский государственный университет. 454080, г. Челябинск, проспект Ленина, 76. E-mail: iushinaid@susu.ru

Барташевич Екатерина Владимировна - доктор химических наук, доцент, заведующий НИЛ многомасштабного моделирования многокомпонентных функциональных материалов НОЦ «Нанотехнологии», профессор кафедры «Теоретическая и прикладная химия», Южно-Уральский государственный университет. 454080, г. Челябинск, проспект Ленина, 76. E-mail: bartashevichev@susu.ru

Поступила в редакцию 30 июня 2020 г.

\section{ОБРАЗЕЦ ЦИТИРОВАНИЯ}

Yushina, I.D. Iodonium Polyiodide Crystals in the Framework of Periodic Calculations with Localized Atomic Basis Sets / I.D. Yushina, E.V. Bartashevich // Вестник ЮУрГУ. Серия «Химия». - 2020. - Т. 12, № 4. - С. 101109. DOI: $10.14529 /$ chem 200407

\section{FOR CITATION}

Yushina I.D., Bartashevich E.V. Iodonium Polyiodide Crystals in the Framework of Periodic Calculations with Localized Atomic Basis Sets. Bulletin of the South Ural State University. Ser. Chemistry. 2020, vol. 12, no. 4, pp. 101-109. (in Russ.). DOI: $10.14529 /$ chem 200407 